\section{Nutrient Intakes and Food}

Consumption Patterns Among Ontario Students in Grades Six, Seven, and Eight

\author{
Rhona M. Hanning, $\mathrm{PhD}, \mathrm{RD}^{1}$ \\ Sarah J. Woodruff, MSc ${ }^{1}$ \\ Irene Lambraki, $\mathrm{MSc}^{1}$ \\ Linda Jessup, $\mathrm{PhD}^{1}$ \\ Pete Driezen, $\mathrm{MSc}^{2}$ \\ Caroline C. Murphy, $\mathrm{BSc}^{3}$
}

\section{ABSTRACT}

Background: The increased prevalence of overweight in Canadian children has stimulated interest in their lifestyle behaviours. The purpose of this research was to investigate dietary intake and food behaviours of Ontario students in grades six, seven, and eight.

Methods: Males and females from grades six to eight were recruited from a stratified random selection of schools from Ontario. Data were collected using the web-based "Food Behaviour Questionnaire", which included a 24-hour diet recall and food frequency questionnaire. Nutrients were analyzed using ESHA Food Processor and the 2001 Canadian Nutrient File database. Body Mass Index (BMI) was calculated based on self-reported weight and height, and classified according to the Centers for Disease Control BMI for age percentiles.

Results: The sample included males $(n=315)$ and females $(n=346)$ in grades 6,7 , and 8 from 15 schools in Ontario. According to Canada's Food Guide to Healthy Eating (CFGHE), median intakes were below recommendations for all participants, with the exception of meat and alternatives. Participants consumed a median of 54\%, 15\%, 31\%, $11 \%$, and $8 \%$ of total energy from carbohydrates, protein, total fat, saturated fat, and added sugars, respectively. Participants consumed $25 \%$ of total energy from foods from the "other" food group (CFGHE). Males had higher intakes of energy, carbohydrates, fat, saturated fat, monounsaturated fat, protein, thiamine, niacin, iron, and zinc than females (all $\mathrm{p}<0.05)$, and consumed more grain products servings $(\mathrm{p}<0.05)$.

Conclusion: The high consumption of "other" foods, at the expense of nutrient-dense food groups, may ultimately be contributing to the increased weights in childhood and adolescence.

MeSH terms: Child; adolescent; food intake; assessment, nutrition; dietary habits

La traduction du résumé se trouve à la fin de l'article.

1. Department of Health Studies and Gerontology, University of Waterloo, Waterloo, ON

2. Population Health Research Group, University of Waterloo

3. Faculty of Medicine, University of British Columbia, Vancouver, BC

Correspondence and reprint requests: Rhona Hanning, Department of Health Studies and Gerontology, University of Waterloo, 200 University Avenue West, Waterloo, ON N2L 3G1, Tel: 519-888-4567, ext. 35685, Fax: 519-746-2510, E-mail: rhanning@healthy.uwaterloo.ca

Acknowledgements: This research was funded by a grant from the Dairy Farmers of Ontario. The authors are grateful for the committed research assistance of Amy MacArthur, Sandra Gibson, and Leia Minaker, and the contribution of Shannon Crocker and Joanne Gallagher to the development and review of the web-based survey.
$\mathrm{O}$ besity is the outcome of an imbalance between energy intake and energy expenditure, and is linked to environment and genetics. ${ }^{1}$ Out of 34 countries, Canada ranked $5^{\text {th }}$ for the highest prevalence of overweight and obese youth (aged 10-16 years). ${ }^{2}$ In 2004, 59\% of Canadian adults ${ }^{3}$ and $26 \%$ of Canadian youth $^{4}$ were classified as either overweight or obese using measured heights and weights. Specifically in Ontario, 28\% of youth were identified as overweight or obese. $^{3}$ Children who are overweight have a 1.5-2 fold higher risk of becoming overweight as adults. ${ }^{5}$ Obesity during childhood and adolescence can have serious short- and long-term health consequences, including increased risk of cardiovascular disease and type 2 diabetes. ${ }^{6-9}$

Low levels of physical activity, ${ }^{10}$ high participation in sedentary activities ${ }^{11,12}$ and poor nutritional behaviours have emerged as priorities in obesity-related research. Data from Canadian studies ${ }^{13-15}$ suggest that the nutrition issues are similar to those described for United States children; specifically, inadequate consumption of milk and dairy products, ${ }^{16}$ and vegetables and fruit, ${ }^{12,16,17}$ while consuming too many high fat, salty snacks, and sugar-sweetened beverages. ${ }^{14,18,19}$ Adolescence is an important developmental stage for learning new behaviours and making choices that may contribute to the problem of obesity. Therefore, the purpose of this research was to investigate dietary intake of Ontario students in grades six, seven, and eight using a web-based school survey.

\section{METHODS}

Schools were recruited from across Ontario using a stratified random selection process. A total of 45 schools, from 18 school boards, were contacted and 15 schools agreed to participate. Of a possible 1,963 eligible students, a total of 772 participated in the study. The $39 \%$ participation rate reflects students' being absent or failing to return parental consent forms. Some participants were excluded from analysis due to incomplete food recalls $(n=58)$, or implausible energy intakes (<200 kcal or $>6000 \mathrm{kcal}, \mathrm{n}=22)$, food group intakes (on visual inspection any record with $>3$ times the upper servings recommendation, $n=11)$, or both $(n=6)$. The final sample included participants 
with complete data for sex $(n=661$; males $=315$, females $=346)$ or grade $(n=662$; grade $6=217$, grade $7=238$, grade $8=207$ ) from 15 schools. There were no systematic differences in age, gender, or estimated BMI between those eliminated and those who remained in the analysis.

Data were collected using the web-based "Food Behaviour Questionnaire" developed at the University of Waterloo. ${ }^{20}$ Participants were asked to report their food intake during meals and snacks on the previous weekday and assess usual consumption patterns of specific foods (milk products, vegetables and fruits, high fat and salty snack foods, cola-type beverages) using a food frequency questionnaire (FFQ) employing a 5-point Likert scale. A number of approaches have established the validity and reliability of this tool. When compared with direct observation of the noon meal from the previous day, the survey produced $87 \%$ agreement in food items selected ( $n=15$, grade 9-10). Compared with dietitian-administered food recall interviews for the same 24-hour period, there was good agreement for energy and key nutrients intakes (intraclass correlation coefficients $>0.65, \mathrm{n}=51$, grade 6-8). Furthermore, test-retest reliability for the FFQ completed 6.5 (SD 5.1) days apart, produced overall percentage agreements of $>60 \%(n=159$, grade $9-10)$.
TABLE I

Body Mass Index Classifications by Gender*

Category $\dagger$

Underweight $\left(<5^{\text {th }}\right.$ percentile)

Normal Weight $\left(>5^{\text {th }}-<85^{\text {th }}\right.$ percentile)

At Risk for Overweight $\left(\geq 85^{\text {th }}-<95^{\text {th }}\right.$ percentile) Overweight $\left(\geq 95^{\text {th }}\right.$ percentile)

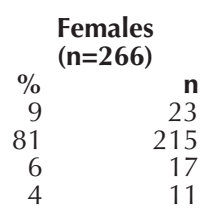

* $\mathrm{n}=524$ due to participants not reporting their height, weight, or sex

$\dagger \mathrm{BMI}$ was classified according to the Centers for Disease Control BMI for age percentiles ${ }^{21}$

This research was approved by the University of Waterloo Office of Research Ethics and each participating school board. Either active or passive parental consent procedures were used based on school preference. The survey took approximately 30-40 minutes to complete. The final screen summed each student's own intake, relative to Canada's Food Guide to Healthy Eating (CFGHE), ${ }^{21}$ based on portion-size definitions of the Canadian Nutrient File group. ${ }^{22}$

BMI was calculated based on students self-reported weight and height, and classified according to the Centers for Disease Control BMI-for-age percentiles..$^{23}$ Selfreported height and weight from the "Food Behaviour Survey" were previously validated against measured values $(\mathrm{r}=0.87$ for height, $r=0.81$ for weight; $n=51$, grade 6-8). ${ }^{20}$ Nutrients (of approximately 500 foods) were analyzed using ESHA Food Processor ${ }^{24}$ and the $2001 \mathrm{~b}$ Canadian Nutrient File ${ }^{22}$ Database (the standard ref- erence food composition database of nutrients in foods commonly consumed in Canada). ${ }^{25}$ Added sugars were distinguished from naturally occurring sugars and estimated by the investigators for the 113 relevant food items. Foods that were not part of the four CFGHE food groups were classified in the "other" food group. For ease of computation, and to support adequate cell sizes, data from the FFQ were collapsed into three categories: at least once a day, at least once a week, and rarely/never. Nutrient intake data are known to be non-normally distributed, ${ }^{26}$ and were therefore transformed using square root transformations (SRT) and Box-Cox transformations (BC) ${ }^{26}$ to permit use of standard statistical tests to compare differences in intakes between sex and grade. Since schools were the unit of randomization and students from the same school are not independent of one another, generalized estimating equation regression

\section{TABLE II}

\section{Median Nutrient Intake and Interquartile Ranges in Male $(n=315)$ and Female $(n=346)$ Participants}

\begin{tabular}{|c|c|}
\hline Nutrient & DA (EAR) or Al \\
\hline \multicolumn{2}{|l|}{ Calories (kcals) } \\
\hline Carbohydrates (g) & 130 \\
\hline Sugar $(g) \dagger$ & \\
\hline Fibre (g) & $31 \neq, 26 \S^{\|}$ \\
\hline \multicolumn{2}{|l|}{ Fat $(\mathrm{g})$} \\
\hline \multicolumn{2}{|l|}{ Saturated Fat (g) } \\
\hline \multicolumn{2}{|c|}{ Monounsaturated Fat (g) } \\
\hline \multirow{2}{*}{\multicolumn{2}{|c|}{$\begin{array}{l}\text { Polyunsaturated Fat (g) } \\
\text { Cholesterol (mg) }\end{array}$}} \\
\hline & \\
\hline Protein $(\mathrm{g})$ & $0.95 \mathrm{~g} / \mathrm{kg}$ \\
\hline Vitamin A ( $\mu g)$ & $600\left(445 \neq * *, 420 \S^{* *}\right)$ \\
\hline Thiamine (mg) & $0.9\left(0.7^{* *}\right)$ \\
\hline Riboflavin (mg) & $0.9\left(0.8^{* *}\right)$ \\
\hline Niacin $(\mathrm{mg})$ & $12(9 * *)$ \\
\hline Vitamin B12 ( $\mu \mathrm{g})$ & $1.8\left(1.5^{* *}\right)$ \\
\hline Vitamin C (mg) & $45(39 * *)$ \\
\hline Vitamin D ( $\mu g)$ & $5 \|$ \\
\hline Folate $(\mu g)$ & $300(250 * *)$ \\
\hline Calcium (mg) & $1300^{\|}$ \\
\hline Iron (mg) & $8\left(5.9 \neq * *, 5.7 \S^{* *}\right)$ \\
\hline Zinc (mg) & $8(7 * *)$ \\
\hline
\end{tabular}

\begin{tabular}{ccc}
\multicolumn{3}{c}{ Males } \\
\hline $\mathbf{2 5}^{\text {th }}$ & Median & $\mathbf{7 5}^{\text {th }}$ \\
1257 & 1838 & 2566 \\
164 & 250 & 342 \\
35 & 64 & 102 \\
7 & 12 & 18 \\
35 & 64 & 98 \\
12 & 22 & 37 \\
10 & 20 & 33 \\
3 & 7 & 13 \\
77 & 174 & 293 \\
41 & 75 & 105 \\
325 & 655 & 1117 \\
0.8 & 1.4 & 2.0 \\
0.9 & 1.7 & 2.5 \\
8.4 & 14.5 & 23.6 \\
1.5 & 3.5 & 5.4 \\
27 & 97 & 185 \\
1.0 & 3.8 & 7.5 \\
148 & 247 & 356 \\
456 & 872 & 1429 \\
7.0 & 11.4 & 16.9 \\
4.7 & 8.2 & 12.3
\end{tabular}

\begin{tabular}{ccc} 
& Females & \\
\hline $\mathbf{2 5}^{\text {th }}$ & Median & $\mathbf{7 5}^{\text {th }}$ \\
1076 & 1508 & 2154 \\
147 & 212 & 288 \\
29 & 57 & 96 \\
6 & 10 & 17 \\
29 & 49 & 76 \\
11 & 16 & 27 \\
8 & 15 & 25 \\
3 & 6 & 11 \\
66 & 134 & 146 \\
37 & 59 & 88 \\
317 & 599 & 1093 \\
0.7 & 1.1 & 1.6 \\
0.8 & 1.4 & 2.1 \\
6.9 & 12.8 & 20.4 \\
1.3 & 2.5 & 4.4 \\
31 & 80 & 166 \\
1.3 & 3.3 & 6.6 \\
145 & 224 & 327 \\
437 & 770 & 1203 \\
5.7 & 9.1 & 13.5 \\
4.1 & 6.5 & 9.9
\end{tabular}

$$
\begin{aligned}
& X^{2} \\
& 8.09^{*} \\
& 6.64^{*} \\
& 2.5 \\
& 0.89 \\
& 8.26^{*} \\
& 6.69^{*} \\
& 11.34^{*} \\
& 3.68 \\
& 3.29 \\
& 5.55^{*} \\
& 1.26 \\
& 5.63^{*} \\
& 3.69 \\
& 4.49^{*} \\
& 3.32 \\
& 1.12 \\
& 1.43 \\
& 1.03 \\
& 3.82 \\
& 5.65^{*} \\
& 4.52^{*}
\end{aligned}
$$

* $\mathrm{p}<0.05$ for effect of gender using Wald Chi-Square test from GEE models

$\dagger$ sugar includes both naturally occurring and added

‡ male

$\S$ female

II Al

the protein requirement is based on body size and therefore, the requirement changes with each individual

** EAR 
TABLE III

$25^{\text {th }}, \mathbf{5 0}^{\text {th }}$, and $75^{\text {th }}$ Percentiles of Servings for Each Food Group by Gender $(n=315$ males, $n=346$ females)

Grain Products Vegetables and Fruit Milk Products Meat and Alternatives Other†

\begin{tabular}{ccc}
\multicolumn{3}{c}{ Males } \\
\hline $\mathbf{2 5}^{\text {th }}$ & $\mathbf{5 0}^{\text {th }}$ & $\mathbf{7 5}^{\text {th }}$ \\
2.3 & 4.6 & 6.9 \\
2.1 & 3.8 & 7.3 \\
1.0 & 2.0 & 4.0 \\
0.9 & 2.3 & 4.5 \\
1.0 & 3.0 & 5.8
\end{tabular}

\begin{tabular}{ccr}
\multicolumn{3}{c}{ Females } \\
\hline $\mathbf{2 5}^{\text {th }}$ & $\mathbf{5 0}^{\text {th }}$ & $\mathbf{7 5}^{\text {th }}$ \\
2.0 & 3.8 & 5.9 \\
1.8 & 4.1 & 6.5 \\
1.0 & 1.8 & 3.1 \\
0.8 & 2.1 & 3.3 \\
1.0 & 2.6 & 4.6
\end{tabular}

$X^{2}$

$3.92^{*}$

1.46

2.57

2.91

2.80

* $p<0.05$ for effect of gender using Wald Chi-Square test from GEE models

$\dagger$ Foods that were not part of the four food groups according to CFGHE were classified in the "other" food group

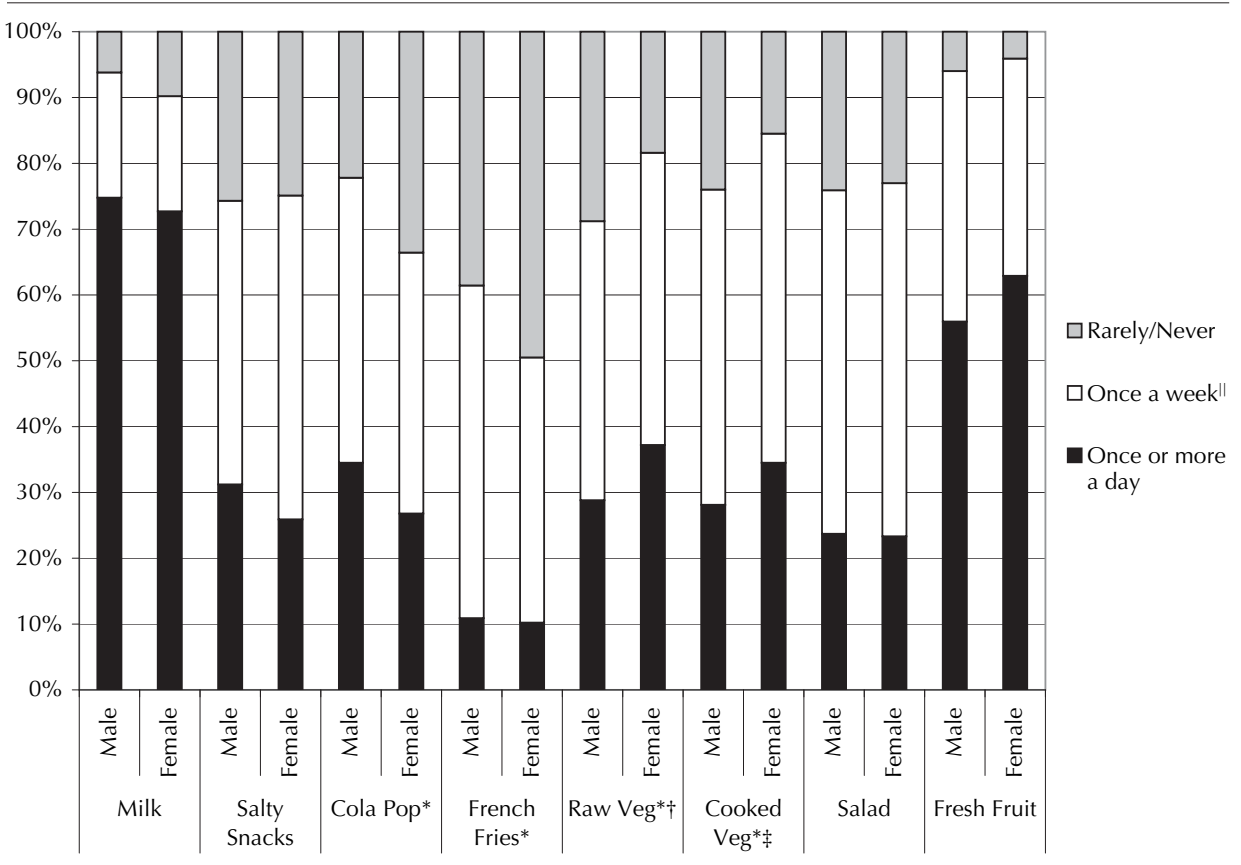

Figure 1. Consumption frequency of selected food items by gender

* $\mathrm{p}<0.05$ for effect of gender using Wald Chi-Square test from GEE models

$\uparrow$ Raw vegetables category does not include salad

$\ddagger$ Cooked vegetables category does not include french fries

II Once a week does not include data from the once or more a day category

models (GEE) were used to account for correlation between observations ${ }^{27}$ (i.e., school clustering). Wald Chi-square tests from these models for the effect of sex or grade were used to test whether nutrient intakes differed significantly. Results presented are from the GEE models based on the preferred transformation or, where neither transformation was preferred, the SRT results. For categorical variables, odds ratios from logistic analyses based on the GEE models were performed. All statistical analyses were made using SAS Statistical Software Package Version 9 (SAS Institute Inc, Cary, NC)..$^{28}$

\section{RESULTS}

BMI classifications for participants providing height and weight data (79\%) indicat- ed that $20 \%$ of males and $10 \%$ of females were considered either at risk for overweight or overweight (Table I). Males had a slightly higher median BMI than females (18.4 vs. 17.7 , respectively), $Z=2.12$, $\mathrm{p}<0.05$.

Median nutrient intakes and interquartile ranges are presented in Table II, by gender. In grades 6,7 , and 8 , males consumed median energy intakes (kcals) of 1615,1833 , and 1987 , respectively, while females consumed median energy intakes (kcals) of 1567, 1642, and 1410, respectively. Males consumed more calories than females, $X^{2}(661)=8.09, \mathrm{p}<0.01$, and there were no significant differences between grades for median energy intake. No differences existed among females across the grades, however, males in grade six consumed significantly lower amounts of pro- tein $(\mathrm{p}<0.05)$, thiamine $(\mathrm{p}<0.01)$, iron $(\mathrm{p}<0.01)$, and zinc $(\mathrm{p}<0.01)$ than those in grade eight, and less iron compared to those in grade seven $(\mathrm{p}<0.01)$. Females were more likely than males to consume less than the estimated average requirements (EAR) for thiamine $(\mathrm{OR}=1.55$, $\mathrm{p}=0.33)$, iron $(\mathrm{OR}=1.79, \mathrm{p}=0.036)$, and zinc $(\mathrm{OR}=1.69, \mathrm{p}=0.001)$ and less than adequate intakes (AI) of vitamin $\mathrm{D}$ $(\mathrm{OR}=1.32, \mathrm{p}=0.013)$ and calcium $(\mathrm{OR}=1.65, \mathrm{p}=0.036)$. Participants consumed a median of $54 \%, 15 \%, 31 \%, 11 \%$, and $8 \%$ of total energy from carbohydrates, protein, total fat, saturated fat, and added sugars, respectively. Although median nutrient intakes generally met the EAR level, they were often below recommended dietary allowances (RDA).

Table III presents the $25^{\text {th }}, 50^{\text {th }}$, and $75^{\text {th }}$ percentiles of food group servings $\left(\mathrm{CFGHE}^{21}\right)$ consumed by gender. Females were significantly less likely to meet the minimum number of recommended servings than boys for grain products $(\mathrm{OR}=1.54, \mathrm{p}=0.011)$, vegetables and fruit $(\mathrm{OR}=1.28, \mathrm{p}=0.010)$ and milk products $(\mathrm{OR}=1.52, \mathrm{p}=0.022)$. Males and females consumed a median of 3.0 and 2.6 servings of food from the "other" food group, respectively, contributing $25 \%$ of total energy.

Results presented in Figure 1 indicate how participants responded to the question, "How often do you eat or drink these foods?" Interestingly, $43 \%$ of males and $38 \%$ of females consumed a vitaminmineral supplement at least once a day.

\section{DISCUSSION}

The nutrient intakes, dietary patterns, and BMI of students in grades six, seven, and eight were obtained through the web-based "Food Behaviour Questionnaire". Although the response rate of students, schools, and boards precluded a truly random sample, our data represent 9 urban and 6 rural schools from Northern $(n=5)$ and Southern $(\mathrm{n}=11)$ Ontario. This is the most comprehensive nutrition survey of Ontario grade 6-8 schools in recent decades.

A greater percentage of females were classified as underweight compared to males while more males were considered either at risk for overweight or overweight. 
The prevalence of overweight and obesity among males is similar to previously reported data, ${ }^{29}$ yet the prevalence among females is lower, especially among those at risk for overweight. Although web-survey reported heights and weights were highly correlated with measured heights and weights in the pilot work,${ }^{20}$ under-reporting is recognized as a potential limitation when using self-reported heights and weights.

Both genders reported somewhat lower energy intakes than students of similar ages from Saskatchewan ${ }^{30}$ and the US ${ }^{16}$ who completed 24-hour dietary recalls and grade five students from Nova Scotia completing a FFQ with standard portion sizes. ${ }^{31}$ Since collection of the Ontariowide data reported herein, the "Food Behaviour Survey" with design upgrades has been used with Ontario students $(\mathrm{n}=684$, grades $6-8)$ from nine schools in the Peel Region, a multi-ethnic region of Southern Ontario. Reported median energy intakes were somewhat higher among this group (males $=2481 \mathrm{kcal} / \mathrm{day}$, females $=1763 \mathrm{kcal} /$ day), similar to other reports. ${ }^{16,30,31}$ However, the same nutrient concerns were identified with the current study and Peel region findings. For example, the prevalence of intakes below the AI for fibre (94\% for both current and Peel) and calcium (current $=73 \%$, Peel $=67 \%$ ), and below the EAR for folate (current $=68 \%$, Peel $=58 \%$ ) were similar. Interestingly, the higher energy intakes from Peel region were largely due to higher consumption of foods from the "other" food category (providing 32\% of total energy versus $25 \%$ in the current study). Therefore, even though the reported energy intake may be somewhat low among our Ontario-wide population, as is typical with diet recalls, ${ }^{32-37}$ the nutritional patterns are largely representative.

As expected, males consumed a greater amount of most nutrients compared to females. Yet, once normalized (per total energy), no differences were seen between the genders, with the exception of fibre $\left(X^{2}(661)=4.73, \mathrm{p}<0.05\right)$, monounsaturated fat $\left(X^{2}(661)=7.28, \mathrm{p}<0.01\right)$, and folate $\left(X^{2}(661)=5.35, \mathrm{p}<0.05\right)$, which were higher for males.

Males and females consumed, on average, one quarter of their energy from the "other" food group. CFGHE ${ }^{21}$ suggests that foods from the "other" food group should be consumed in moderation as they are higher in fat and/or calories. Clearly, these are "everyday" and not "sometimes" foods for many students. A median of 30\% of total fat, $24 \%$ of saturated fat, and $56 \%$ of added sugar intakes were consumed from the "other" food group category. The high proportion of energy from "other" foods is similar to data from an older sample of Canadian adolescents. ${ }^{14}$ Diets high in low-nutrient-dense foods ${ }^{16}$ and/or high in added sugars ${ }^{38}$ have been associated with higher energy intakes, and lower intakes of vitamins $\mathrm{A}_{1} \mathrm{~B}_{6}, \mathrm{~B}_{12}$, folate, calcium, magnesium, iron, and zinc. Such diets can contribute to the health risk factors of overweight and elevated blood cholesterol. ${ }^{39}$

The majority of participants reported consuming fresh fruit and fruit or vegetable juice "at least once a day", while consuming salad, other vegetables (raw), and other vegetables (cooked) "at least once a week". Alarmingly, over one quarter of males claimed to eat vegetables rarely or never. Results of the 24-hour recall confirmed that the median intakes of vegetables and fruit servings of both genders fell below CFGHE recommendations. ${ }^{21}$ Higher intakes of vegetables and fruit increase the chance of achieving recommended intakes of fibre and micronutrients and may assist in interventions for overweight/obese children. ${ }^{40}$ Sources other than juice should be emphasized to increase fibre intakes and benefits (e.g., in glycemic control). ${ }^{41}$

It should be noted that there are limitations associated with using 24-hour dietary recalls and FFQ. Self-reported survey data have the potential for recall error, inaccurate estimation of portion sizes, systematic bias in dietary reporting, and providing socially desirable answers. ${ }^{37}$ The web-based survey, however, was designed to minimize these limitations, with built-in prompts to assist student memory and visuals to assist in portion size estimation.

In summary, the food behaviour of Ontario students was characterized by high consumption of energy from the "other" food group category at the expense of nutrient-dense food groups. Ultimately, this unhealthy pattern may contribute to increased body weight in childhood and adolescence. These data stress the urgency of the call to action for programs and policies to address the determinants of unhealthy food behaviours and to support healthier lifestyle choices of children. ${ }^{42,43}$

\section{REFERENCES}

1. Rosenbaum M, Leibel RL, Hirsh J. Obesity. N Engl J Med 1997;337(6):396-407.

2. Janssen I, Katzmarzyk PT, Boyce WF, Vereecken C, Mulvihill C, Roberts C, et al. Comparison of overweight and obesity prevalence in school-aged youth from 34 countries and their relationships with physical activity and dietary patterns. Obes Rev 2005;6(2):123-32.

3. Tjepkema M. Adult obesity in Canada: Measured height and weight (Statistics Canada). Available online at: http://www.statcan.ca/english/research/ $82-620-\mathrm{MIE} / 2005001 / \mathrm{pdf} /$ aobesity.pdf (Accessed December 2006)

4. Shields M. Overweight Canadian children and adolescents (Statistics Canada). Available online at: http://www.statcan.ca/english/research/ 82-620-MIE/2005001/pdf/cobesity.pdf (Accessed December 2006)

5. Nicklas TA, Baranowski T, Cullen KW, Berenson G. Eating patterns, dietary quality, and obesity. J Am Coll Nutr 2001;20(6):599-608.

6. Freedman DS, Dietz WH, Srinivasan SR, Berenson GS. The relation of overweight to cardiovascular risk factors among children and adolescents: The Bogalusa Heart Study. Pediatrics 1999; 103:1175-82.

7. Ball GD, McCargar LJ. Childhood obesity in Canada: A review of prevalence estimates and risk factors for cardiovascular disease and type 2 diabetes. Can J Appl Physiol 2003;28(1):117-40.

8. Fagot-Campagna A, Pettitt DJ, Engelgau MM, Burrows NR, Geiss LS, Valdez R, et al. Type 2 diabetes among North American children and adolescents: An epidemiology review and a public health perspective. J Pediatr 2000;136(5):664-72.

9. Wiegand S, Maikowski U, Blankenstein O, Biebermann H, Tarnow P, Gruters A. Type 2 diabetes and impaired glucose tolerance in European children and adolescents with obesity A problem that is no longer restricted to minority groups. Eur J Endocrinol 2004;151(2):199-206.

10. Canadian Fitness and Lifestyle Research Institute (CFLRI): 2002 Physical Activity Monitor. Available online at: http://www.cflri.ca/cflri/ pa/surveys/2002survey/2002survey.html\#kids (Accessed August 2004).

11. Bar-Or O, Foreyt J, Bouchard C, Brownell KD, Dietz WH, Ravussin E, et al. Physical activity, genetic, and nutritional considerations in childhood weight management. Med Sci Sports Exerc 1998;30:2-10.

12. Lowry R, Wechsler H, Galuska DA, Fulton JE, Kann L. Television viewing and its associations with overweight, sedentary lifestyle, and insufficient consumption of fruits and vegetables among US high school students: Differences by race, ethnicity, and gender. I Sch Health 2002;72(10):413-21.

13. Cohen B, Evers S, Manske S, Bercovitz K, Edward HG. Smoking, physical activity and breakfast consumption among secondary school students in a Southwestern Ontario community. Can J Public Health 2003;94(1):41-44.

14. Phillips S, Jacobs-Starkey L, Gray-Donald K. Food habits of Canadians: Food sources of nutrients for the adolescent sample. Can J Diet Pract Res 2004;65(2):81-84.

15. Garriguet D. Overview of Canadians' Eating Habits 2004 (Statistics Canada). 2006. Available online at: http://www.statcan.ca/english/research/ 82-620-MIE/ 82-620-MIE2006002.pdf (Accessed December 2006).

16. Briefel RR, Johnson CL. Secular trends in dietary intake in the United States. Annu Rev Nutr 2004;24:401-31. 
17. Gibson EL, Wardle J, Watts CJ. Fruit and vegetable consumption, nutritional knowledge and beliefs in mothers and children. Appetite 1998;31(2):205-28.

18. Ludwig DS, Peterson KE, Gortmaker SL. Relation between consumption of sugarsweetened drinks and childhood obesity: A prospective, observational analysis. Lancet 2001;357(9255):505-8.

19. Troiano RP, Briefel RR, Carroll MD, Bialostosky K. Energy and fat intakes of children and adolescents in the United States: Data from the national health and nutrition examination surveys. $A m J$ Clin Nutr 2000;72(5 suppl):1343s-53s.

20. Hanning RM, Jessup L, Lambraki I, MacDonald C, McCargar L. A web-based approach to assessment of food intake and behaviour of school children and adolescents [Abstract]. Can J Diet Pract Res 2003;64(2);s110.

21. Minister of Public Works and Government Services Canada. Canada's Food Guide to Healthy Eating. Cat No H39-252/1992E. ISBN 0-662-19648-1.

22. Canadian Nutrient File 2001b. Health Canada. Available online at: http://www.hc-sc.gc.ca/foodaliment/ns-sc/nr-rn/surveillance/cnffcen/e_index.html (Accessed August 2004).

23. Kuczmarski RJ, Ogden CL, Grummer-Strawn LM, Flegal KM, Guo SS, Wei R, et al. CDC growth charts: United States. Adv Data 2000;314(4):1-27.

24. ESHA Research. The Food Processor, Nutrition Analysis and Fitness Software (Version 7.9) [Computer software]. 1987-2002: Salem, OR.

25. The Canadian nutrient data system. Health Canada. Available online at: http://www.hcsc.gc.ca/fn-an/nutrition/fiche-nutri-data/ cnds_vision_scdn_e.html (Accessed February 2006).

26. Millns H, Woodward M, Bolton-Smith C. Is it necessary to transform nutrient variables prior to statistical analysis? $A m$ E Eidemiol 1995;141(3):251-62.

27. Horton NJ, Lipsitz SR. Review of software to fit generalized estimating equation regression models. The American Statistician 1999;53:160-69.

28. SAS Institute Inc. SAS Statistical Software Package (Version 9) [Computer software]. Cary, NC.

29. Tremblay MS, Willms JD. Secular trends in the body mass index of Canadian children. CMAJ 2000;163(11):1429-33

30. Carter LM, Whiting SJ, Drinkwater DT, Zello GA, Faulkner RA, Bailey DA. Self-reported calcium intake and bone mineral content in children and adolescents. J Am Coll Nutr 2001;20(5):5029.

31. Veugelers PJ, Fitzgerald AL, Johnston E. Dietary intake and risk factors for poor diet quality among children in Nova Scotia. Can J Public Health 2005;96(3):212-16.
32. Bandini LG, Must A, Cyr H, Anderson SE, Spadano JL, Dietz WH. Longitudinal changes in the accuracy of reported energy intake in girls 10 15 y of age. Am J Clin Nutr 2003;78(3):480-84.

33. Johansson L, Solvoll K, Bjorneboe GE, Drevon CA. Under- and overreporting of energy intake related to weight status and lifestyle in a nationwide sample. Am J Clin Nutr 1998;68(2):266-74.

34. Champagne CM, Baker NB, DeLany JP, Harsha DW, Bray GA. Assessment of energy intake underreporting by doubly labeled water and observations on reported nutrient intakes in children. I Am Diet Assoc 1998;98(4):426-33.

35. Johnson-Down L, O'Loughlin J, Koski K, GrayDonald K. High prevalence of obesity in low income and multiethnic schoolchildren: A diet and physical activity assessment. J Nutr 1997;187(12):2310-15.

36. Lissner L. Measuring food intake in studies of obesity. Public Health Nutr 2002;5(6A):889-92.

37. Gibson RS. Principles of Nutrition Assessment, $2^{\text {nd }}$ Ed. New York: Oxford University Press, 2005.

38. Bowman SA. Diets of individuals based on energy intakes from added sugars. Family Eco Nutr Rev 1999;12(2):31-38.

39. Institute of Medicine of the National Academies. Dietary reference intakes: Energy, carbohydrate, fiber, fat, fatty acids, cholesterol, protein, and amino acids (Prepublication copy, unedited proofs). Washington, DC, 2002.

40. Epstein LH, Gordy CC, Raynor HA, Beddome $\mathrm{M}$, Kilanowski CK, Paluch R. Increasing fruit and vegetable intake and decreasing fat and sugar intake in families at risk for childhood obesity. Obes Res 2001;9(3):171-78.

41. Position Statement by the Canadian Diabetes Association. Guidelines for the nutritional management of diabetes mellitus in the new millenium. Can J Diabetes Care 1999;23(3):56-69.

42. Taylor JP, Evers S, McKenna M. Determinants of healthy eating in children and youth. Can J Public Health 2005;96(Suppl. 3):S20-S26.

43. Ontario Society of Nutrition Professionals in Public Health School Nutrition Workgroup Steering Committee. Call to action: Creating a healthy school nutrition environment. 2004; March. Available online at: http://www.osnpph.on.ca/pdfs/call_to_action.pdf (Accessed December 2006).

Received: October 14, 2005

Accepted: July 11, 2006

\section{RÉSUMÉ}

Contexte : La prévalence accrue du surpoids chez les enfants canadiens ravive l'intérêt pour les comportements liés au mode de vie des enfants. Notre étude portait sur les apports et les comportements alimentaires d'élèves ontariens de $6^{\mathrm{e}}, 7^{\mathrm{e}}$ et $8^{\mathrm{e}}$ année.

Méthode : Nous avons recruté des garçons et des filles de la $6^{\mathrm{e}}$ à la $8^{\mathrm{e}}$ année à partir d'un échantillon aléatoire stratifié d'écoles de l'Ontario. Les données ont été recueillies à l'aide d'un questionnaire en ligne sur les comportements alimentaires, incluant une feuille de rappel des aliments ingérés pendant les 24 dernières heures et un questionnaire sur la fréquence de consommation des produits alimentaires. Les nutriments ont été analysés avec le logiciel Food Processor d'ESHA Research et la version 2001 du Fichier canadien sur les éléments nutritifs. L'indice de masse corporelle (IMC) a été calculé d'après le poids et la taille déclarés par les répondants, puis classé selon les centiles d'IMC selon I'âge publiés par les Centres américains de contrôle des maladies.

Résultats : L'échantillon comportait des garçons $(n=315)$ et des filles $(n=346)$ des classes de $6^{e}, 7^{e}$ et $8^{\mathrm{e}}$ année de 15 écoles de l'Ontario. Selon le Guide alimentaire canadien pour manger sainement (GACMS), les apports médians étaient inférieurs aux recommandations chez tous les participants, sauf les apports en viandes et substituts. Les participants consommaient en moyenne $54 \%, 15 \%, 31 \%, 11 \%$ et $8 \%$ de leur apport énergétique total sous forme de glucides, de protéines, de matières grasses en général, de graisses saturées et de sucres ajoutés, respectivement. Le quart $(25 \%)$ de l'apport énergétique alimentaire total provenait du groupe " autres aliments » (GACMS). Les garçons avaient des apports plus élevés en calories, en glucides, en matières grasses, en graisses saturées, en graisses monoinsaturées, en protéines, en thiamine, en niacine, en fer et en zinc que les filles ( $<<0,05$ dans tous les cas), et ils consommaient plus de portions de produits céréaliers $(p<0,05)$.

Conclusion : La consommation élevée des " autres aliments » aux dépens des groupes riches en éléments nutritifs pourrait en bout de ligne contribuer aux gains de poids observés durant l'enfance et I'adolescence. 